\title{
STANDARISASI DUNIA PENDIDIKAN
}

\author{
Oleh \\ Putu Subawa \\ Tenaga Pendidik pada STAHN Mpu Kuturan Singaraja
}

\begin{abstract}
The educational issues that stuck out today, includes equalization of educational opportunities, quality improvement/quality, relevance and efficiency of education. Serious problems that are still felt by education from primary education to higher education is a quality problem, of course, this can be solved through technological approach to education. The use of technology in education itself has three principles that dijadiakan as a reference for the development and utilization is a systems approach, oriented to students, as well as the use of learning resources. Competence of graduates who must be the benchmark in this regard in order to form a generation of people who have the competitiveness of a competitive and innovative. The role of educators is expected to further motivate himself in each learning interaction. Transformative educators believe that students should have the ability to be actively involved in the history of the creation of man.
\end{abstract}

\section{Keywords: Standardization, Education}

\section{PENDAHULUAN}

Pemerintah Republik Indonesia mengeluarkan kembali peraturan nomor 13 tahun 2015 tentang perubahan kedua atas peraturan pemerintah nomor 19 tahun 2005 tentang Standar Nasional pendidikan, hal ini terkait munculnya berbagai isu penting dalam dunia pendidikan di Indonesia. Kualitas pendidikan di Indonesia dewasa ini banyak mendapat sorotan dan kritikan dari dalam negeri maupun luar negeri. Menteri Riset Teknologi dan Perguruan Tinggi (Menristek Dikti), Prof.Dr. Mohammad Nasir, PhD mengungkapkan, kualitas pendidikan dan daya saing lulusan perguruan tinggi (PT) di Indonesia masih jauh tertinggal, terutama di level internasional. Menurutnya, peningkatan mutu harus serius. Harapan masyarakat terhadap pendidikan tinggi tidak lagi cukup sebagai agen pendidikan ataupun riset.

Pendidikan tinggi kini diharapkan jadi agen pembangunan ekonomi. Untuk itu, lanjutnya, perguruan tinggi tidak cukup menghasilkan lulusan dan riset yang baik, tetapi juga menghasilkan sarjana yang hebat berinovasi. Beberapa tahun silam majalah Asia Weeks juga pernah memuatkan beberapa perguruan tinggi ternama dan berkualitas di benua Asia, perguruan tinggi ternama Indonesia menempati urutan jauh di belakang negara tetangga, seperti: Malaysia, Singapura, Korea, China, dan negara lain. Para pakar pendidikan Indonesia mendesak pemerintah untuk membenahi mutu pendidikan di Indonesia, mulai dari Taman Kanak-Kanak sampai Perguruan Tinggi.

Menurut survei internasional yang komprehensif pada tahun 2003 oleh Organization for Economic Cooperation and Development (OECD). Kualitas pendidikan terbaik di dunia adalah kualitas pendidikan di Negara Finlandia. Bagaimana dengan kualitas pendidikan di Indonesia? 
Kualitas pendidikan Indonesia saat ini masih rendah dan bisa dibilang memprihatinkan. Masih sering dijumpai bangunan sekolah yang buruk kondisinya. Bahkan sekolah-sekolah yang beratapkan langit pun masih banyak. Siswa tidak mendapatkan pasokan buku yang memadai. Dan yang fatal lagi adalah mahalnya biaya sekolah. Padahal kita semua tahu bahwa pendidikan merupakan hak bagi seluruh warga negara Indonesia. Inilah realita yang dialami dunia pendidikan di Indonesia. Kondisi di ataslah yang menghambat Indonesia untuk bisa bangkit mengatasi masalah rendahnya kualitas sumber daya manusia serta tingginya angka pengangguran. Minimnya kualitas dan fasilitas pendidikan tentunya berdampak secara signifikan terhadap kualitas manusia itu sendiri. Begitu banyaknya masalah yang dihadapi pemerintah tentunya tidak bisa kita selesaikan secara cepat.

Sekarang ini banyak sekali perguruan tinggi di Indonesia bak jamur tumbuh di musim hujan, setiap perguruan tinggi telah banyak melahirkan lulusannya, mulai dari gelar ahli madya sampai tingkat doctor, akan tetapi sebagian dari mereka belum cukup dibekali keterampilanketerampilan dan hanya dibekali dengan muatan kognisi/pengetahuan, contohnya banyak sekali orang-orang cerdas dan pintar akan tetapi kurang mampu berbuat banyak untuk masyarakat dan Bangsa Indonesia.

\section{PEMBAHASAN}

A. Peningkatan Profesionalisme

Dalam Kamus Besar Indonesia, profesionalisme mempunyai makna; mutu, kualitas, dan tindak tanduk yang merupakan ciri suatu profesi atau yang profesional. Profesionalisme merupakan sikap dari seorang profesional. Artinya sebuah term yang menjelaskan bahwa setiap pekerjaan hendaklah dikerjakan oleh seseorang yang mempunyai keahlian dalam bidangnya atau profesinya. Menurut Supriadi, penggunaan istilah profesionalisme menunjuk pada derajat penampilan seseorang sebagai profesional atau penampilan suatu pekerjaan sebagai suatu profesi, ada yang profesionalismenya tinggi, sedang dan rendah. Profesionalisme juga mengacu kepada sikap dan komitmen anggota profesi untuk bekerja berdasarkan standar yang tinggi dan kode etik profesinya. Konsep profsionalisme, seperti dalam penelitian yang dikembangkan oleh Hall, kata tersebut banyak digunakan peneliti untuk melihat bagaimana para profesional memandang profesinya, yang tercermin dari sikap dan perilaku mereka. . Berdasarkan defenisi tersebut maka profesionalisme adalah konsepsi yang mengacu pada sikap seseorang atau bahkan bisa kelompok, yang berhasil memenuhi unsur-unsur tersebut secara sempurna.

Profesional tersebut memiliki beberapa indikator :

- Orang yang tahu akan keahlian dan keterampilannya.

- Meluangkan seluruh waktunya untuk pekerjaan atau kegiatannya itu.

- Hidup dari situ.

- Bangga akan pekerjaannya.

Dengan melihat ciri-ciri umum di atas, dapat disimpulkan bahwa kaum profesional adalah orang-orang yang memiliki tolak ukur perilaku yang berada di atas ratarata. Di satu pihak ada tuntutan dan tantangan yang sangat berat, tetapi di lain pihak ada suatu kejelasan mengenai pola perilaku yang baik dalam rangka kepentingan masyarakat. Seandainya semua bidang kehidupan dan bidang kegiatan menerapkan suatu estandar profesional yang tinggi, bisa diharapkan akan tercipta suatu kualitas masyarakat yang semakin baik.

\section{B. Pemanfaatan Perkembangan Teknologi Adanya teknologi saat ini harus disikapi baik oleh dunia pendidikan hal tersebut mengingat efektivitas dan efisiensi dan teknologi tidak dapat dipisahkan dari masalah, sebab teknologi lahir dan dikembangkan untuk memecahkan permasalahan yang dihadapi oleh}


manusia. Pemanfaatan teknologi dalam dunia pendidikan merupakan sesuatu yang abstrak jika dilihat dari prosesnya. Dalam hal ini teknologi dalam dunia pendidikan harus bisa dipahami ide, peralatan, dan organisasi untuk menganalisis masalah, mencari jalan untuk mengatasi permasalahan,melaksanakan,menilai, dan mengelola pemecahan masalah tersebut yang mencakup semua aspek belajar manusia. Sejalan dengan hal tersebut, maka lahirnya pemanfaatan teknologi dalam dunia pendidikan merupakan sebuah solusi dalam mengatasi permasalahan dalam pendidikan.

Permasalahan pendidikan yang mencuat saat ini, meliputi pemerataan kesempatan memperoleh pendidikan, peningkatan mutu / kualitas, relevansi, dan efisiensi pendidikan. Permasalahan serius yang masih dirasakan oleh pendidikan mulai dari pendidikan dasar hingga pendidikan tinggi adalah masalah kualitas, tentu saja ini dapat di pecahkan melalui pendekatan teknologi pendidikan. Pemanfaatan teknologi dalam dunia pendidikan sendiri memiliki tiga prinsip yang dijadiakan sebagai acuan pengembangan serta pemanfaatan yaitu pendekatan sistem, berorientasi pada peserta didik, serta pemanfaatan sumber belajar.

Perkembangan teknologi informasi yang sedang dikembangan oleh negara kita adalah e-Education(electroni education) yang juga merupakan istilah penggunaan IT dalam pendidikan. Yang mana merupakan sebuah media akses informasi tentang pendidikan yang mencakup didalamnya. Kemudian diharapkan dengan hadirnya suatu usaha yang dilakukan oleh pemerintah ini merupakan suatu wadah informasi yang bisa diharapkan dapat meningkatkan citra negara kita khususnya dibidang pendidikan. Dalam dunia pendidikan teknologi memiliki peran yang sangat penting. Contohnya saja media internet yang digunakan pengajar dapat memberikan pelajaran online untuk anak didiknya. Lalu dalam lingkup pendidikan tinggi dosen dapat memberikan tugas kepada mahasiswanya melalui email.

\section{Standarisasi Lulusaan}

UU Sisdiknas No.20 tahun 2003 pasal 35 (ayat 1) dengan delapan kriteria yang telah disebut diatas dan PP No.19 tahun 2005 pasal 25 (ayat 1) menyebutkan "Standar kompetensi lulusan digunakan sebagai pedoman penilaian dalam penentuan kelulusan peserta didik dari satuan pendidikan". Undang-undang dan peraturan pemerintah ini merupakan paying pencerahan pendidikan Indonesia, peningkatan mutu suatu hal yang tidak dapat ditawartawarkan lagi, menetapkan standar lulusan suatu hal yang berat tetapi mesti dilakukan. di Indonesia tahun 2005 ini, belum ada suatu sekolah, madrasah, dan perguruan tinggi yang menerapkan standar lulusan namun sebagian kecil sekolah, madrasah dan perguruan tinggi yang memperlihatkan keunggulan masingmasing hal ini sudah menunjukkan pembenahan kualitas lulusan.

Kemenade dan Garre (2003;33) menyebutkan standarisasi lulusan perguruan tinggi di negara-negara Eropa seperti: Belgia, Belanda, Finlandia dan Inggrissudah menjadi kemutlakan untuk memenuhi permintaan bisnis dan industridengan mempersyaratkan delapan kategori yaitu: (1) berorientasi pada pelanggan, (2) memiliki pengetahuan praktis dan aplikasi alat-alat total quality management (TQM), (3) mampu membuat keputusan berdasarkan fakta, (4) memiliki pemahaman bahwa bekerja adalah suatu proses, (5) berorientasi pada kelompok (teamwork), (6) memiliki komitmen untuk peningkatan terus menerus, (7) pembelajaran aktif (active learning), dan (8) memiliki perspektif sistem.

Peraturan Pemerintah Republik Indonesia No.19/2005pasal 25 (ayat 2) member maksud standar kompetensi lulusan meliputi kompetensi untuk seluruh mata pelajarab atau kelompok mata pelajaran dan mata kuliah atau kelompok mata kuliah.

Kemudian diperinci lebih jelas dalam pasal 26 bahwa standar kompetensi lulusan setiap jenjang pendidikan dapat dilihat pada ayat: 
(1) Standar kompetensi lulusan pada jenjang pendidikan dasar bertujuan untuk meletakkan dasar kecerdasan, pengetahuan, kepribadian, akhlak mulia serta keterampilan untuk hidup mandiri dan mengikuti pendidikan lebih lanjut.

(2) Standar kompetensi lulusan pada satuan pendidikan menengah umum bertujuan untuk meningkatkan kecerdasan, pengetahuan, kepribadian, akhlak mulia, serta keterampilan untuk hidup mandiri dan mengikuti pendidikan lebih lanjut

(3) Standar kompetensi lulusan pada satuan pendidikan menengah kejuruan bertujuan untuk meningkatkan kecerdasan, pengetahuan, kepribadian, akhlak mulia serta keterampilan untuk hidup mandiri dan mengikuti pendidikan lebih lanjut sesuai dengan kejuruannya.

(4) Standar kompetensi lulusan pada jenjang pendidikan tinggi bertujuan untuk mempersiapkan peserta didik menjadi anggota masyarakat yang berakhlak mulia, memiliki pengetahuan, keterampilan, kemandirian dan sikap untuk menemukan, mengembangkan, serta menerapkan ilmu, teknologi, dan seni yang bermanfaat bagi kemanusiaan.

Jadi jelaslah kopetensi lulusan yang mesti menjadi tolak ukur dalam hal ini guna membentuk generasi bangsa yang memiliki daya saing yang kompetitif dan inovatif. Peran pendidik sangat diharapkan guna lebih memotivasi dirinya dalam setiap interaksi pembelajaran. Pendidik transformatif harus menyakini bahwa peserta didik memiliki kemampuan untuk terlibat secara aktif dalam sejarah penciptaan manusia. Pertanyaan yang selalu harus dimunculkan pada peserta didiknya : jika kita mampu memproduksi sejarah dunia (keadaan kita), mengapa kita tak mampu mengubahnya?

\section{SIMPULAN}

Dari uraian yang dipaparkan diatas maka dapat ditarik beberapa kesimpulan yaitu :

1. Seandainya semua bidang kehidupan dan bidang kegiatan menerapkan suatu estandar profesional yang tinggi, bisa diharapkan akan tercipta suatu kualitas masyarakat yang semakin baik.

2. Dalam dunia pendidikan teknologi memiliki peran yang sangat penting. Lahirnya pemanfaatan teknologi dalam dunia pendidikan merupakan sebuah solusi dalam mengatasi permasalahan dalam pendidikan.

3. Pendidik transformatifharus menyakini bahwa peserta didik memiliki kemampuan untuk terlibat secara aktif dalam sejarah penciptaan manusia.

\section{DAFTAR PUSTAKA}

A. M, Sardiman. (2011). Interaksi dan motivasi belajar mengajar. Jakarta: PT Raja Grafindo Persada

Dahar, R. W. (1996). Teori-teori belajar. Jakarta: PT Erlangga.

Eggen, P. \& Kauchak, D. (2012). Strategi dan model pembelajaran. (edisi keenam). Jakarta: PTIndeks.

Ermasari, G., Subagia I W., \& Sudria, Ida Bagus Nyoman. (2014). Kemampuan bertanyaguru IPA dalam pengelolaan pembelajaran. E-journal Program Pascasarjana Universitas Pendidikan Ganesha. Volume 4.

Hasibuan, J.J., Ibrahim, \& Tolience, A. J. E. (1988). Proses belajar mengajar keterampilan dasar pengajawan mikro. Bandung: Remadja Karya. 
Heriawan, A., Darmajari, \& Senjaya, A. (2002). Metodologi pembelajaran kajian teoretis praktis. Banten: LP3G.

Jacobsen, D. A., Eggen, P. \& Kauchak, D. (2009). Metode-metode pengajaran meningkatkan belajar siswa TKSMA. (edisi kedelapan). Yogyakarta: Pustaka Pelajar.

Khoerunnisa, R. (2012). Pengaruh strategi questioning berbantuan komputer terhadap penguasaan konsep siswa kelas XI pada konsep sistem saraf. (Skripsi). FPMIPA, Universitas Pendidikan Indonesia, Bandung.

Nitasari, N. I. (2013). Interaksi dalam pembelajaran. [Online]. Diakses dari http://nasriaika1125.wordpress.com/ $2013 / 09 / 28 /$ interaksi-dalampembelajaran/

Pujiastuti, S. (2008). Pentingnya Pertanyaan dalam Proses Pembelajaran. [Online]. Diakses dari http://www. sdbinatalenta.com/arsipartikel/artikel_tya. pdf.
Sirodjuddin, Ardan. 2014. Mengapa Pendidikan Indonesia Saat ini Tidak Mampu Menciptakan G e n e r a s i Hebat?. Penerbit :Guraru Tamam,

Rosid. 2014. Tunjangan Profesi Guru Meningkatkan Mutu Pendidikan ? Penerbit :Guraru

Rustaman, N. dkk. (2005). Strategi belajar dan mengajar Biologi. Malang: UM Press.

Rustaman, N. Y., Rustaman, A. (2003). Peranan pertanyaan produktif dalam pengembangan KPS dan LKS. Bahan seminar dan lokakarya bagi guruguru Biologi SLTP \& SMU. Bandung: Depdiknas.

Sudjana, N. (1989). Dasar-dasar proses mengajar. Bandung: Sinar BaruAlgensindo.

Widodo, A. (2006a). Profil pertanyaan guru \& siswa dalam pembelajaran sains. Jurnal pendidikan dan pembelajaran. 4(2), 139148.

Widodo, A. (2006b). Taksonomi Bloom dan pengembangan butir soal. Buletin Puspendik. 3(2), 18-29. 